\title{
CHANGES OF INTESTINAL MICROBIOTA AND IVABRADINE BIOTRANSFORMATION IN RATS AFTER ALCOHOL INTRODUCTION
}

(C) 2017

Tolkachev Boris Evgenyevich, candidate of medical sciences, associate professor of Fundamental Medicine and Biology Department Volgograd State Medical University (Volgograd, Russian Federation)

Morkovin Evgeny Igorevich, candidate of medical sciences, associate professor of Fundamental Medicine and Biology Department; senior researcher of Genomic and Proteomic Researches Laboratory

Knyshova Liliya Petrovna, postgraduate student of Clinical Laboratory Diagnostics Department; junior researcher of Genomic and Proteomic Researches Laboratory Volgograd State Medical University (Volgograd, Russian Federation); Volgograd Medical Research Center (Volgograd, Russian Federation) Yakovlev Anatoly Trofimovich, doctor of medical sciences, professor, head of Clinical Laboratory Diagnostics Department Volgograd State Medical University (Volgograd, Russian Federation)

Strygin Andrey Valeryevich, candidate of medical sciences, head of Fundamental Medicine and Biology Department; head of Genomic and Proteomic Researches Laboratory Volgograd State Medical University (Volgograd, Russian Federation); Volgograd Medical Research Center (Volgograd, Russian Federation)

Abstract. The role of intestinal microbiota in progress of many pathological processes is discussed in recent publications. It was shown that the continuous intestinal dysbiosis, including the increased bacterial growth syndrome, affects the digestion and the biotransformation of xenobiotics. Intestinal microbiota provokes metabolic failures leading to severe diseases acting via several mechanisms. Alcohol is found to be a common dysbiotic factor and toxic agent affecting the systems of biotransformation. This study was to estimate the associations between the intestinal microbiota and the biotransformation of ivabradine, CYP3A4 substrate, in rats during the chronic alcohol intake. The study used 30 male Wistar rats divided into two groups - control and experimental, administrated $15 \%$ ethanol as a sole water supply during 40 days to model the chronic alcohol intake. The decrease of bifido- and lactobacterium spp. found in experimental group correlated with excretion and metabolic ratio of ivabradine metabolite and ivabradine in urine. These findings demonstrate the participation of intestinal microbiota in the metabolism of ivabradine after oral introduction.

Keywords: xenobiotics; ivabradine; biotransformation; metabolism; intestinal microbiota; dysbiotic processes; probiotic strains; increased bacterial growth syndrome; microbal toxins; endotoxemia; experimental modeling; alcohol; chronic alcohol intake; liver; CYP3A4.

УДК 574.52

Статья поступила в редакцию 05.06.2017

\section{ПРЕДСТАВИТЕЛИ РУЧЕЙНИКОВ ПОДОТРЯДА INTЕGRIPALPIA В СИСТЕМЕ ЭКОЛОГИЧЕСКОГО МОНИТОРИНГА РЕК ЮЖНОГО УРАЛА}

(C) 2017

\author{
Чаус Борис Юрьевич, кандидат биологических наук, доцент кафедры биологии \\ Стерлитамакский филиал Башкирского государственного университета \\ (2. Стерлитамак, Республика Башкортостан, Российская Федерация)
}

Аннотация. В статье приводится анализ возможности использования личинок ручейников подотряда Integripalpia для повышения значимости биоиндикационных исследований в ходе экологического мониторинга рек Южного Урала. Сбор и анализ постоянства видов (в долях единицы) ручейников проводился в районах 17 государственных водопостов, находящихся на реках, протекающих по территории Южного Урала, с 2005 по 2016 годы. В качестве химических характеристик на створах использовались такие показатели, как содержание в речных водах соединений марганца, никеля и железа, нефтепродуктов, фенолов, азота аммонийного, меди, цинка, ХПК, БПК 5 , сульфатов, хлоридов, азота нитритного. В качестве комплексного показателя использовался удельный комбинаторный индекс загрязненности воды. Всего в районах проведения исследований была проанализирована динамика постоянства 7 видов личинок ручейников, относящихся к подотряду Integripalpia. Впервые составлен список постоянных, добавочных и случайных видов Integripalpia на изученных участках рек Южного Урала. Выявлены статистически значимые корреляционные зависимости между постоянством личинок видов ручейников с рядом гидрохимических показателей. Построены регрессионные модели для прогноза постоянства личинок видов подотряда Integripalpia в зависимости от концентрации поллютантов, содержащихся в речных водах. Сочетание динамики постоянства личинок видов ручейников подотряда Integripalpia c результатами гидрохимических анализов позволит выявить наиболее сильно действующие на гидробионтов загрязняющие химические вещества, входящие в состав сточных вод, сбрасываемых в поверхностные воды Южного Урала.

Ключевые слова: биоиндикация; ручейники; личинки ручейников; подотряд Integripalpia; Южный Урал; постоянство видов; динамика постоянства; гидрохимические показатели; поллютанты; удельный комбинаторный индекс загрязненности воды; корреляционные модели; регрессионные модели. 


\section{Введение}

Контроль за качеством водной среды осуществляется в настоящее время, в основном, посредством химических и физико-химических методов. Однако анализ отдельных химических веществ не в состоянии дать полную характеристику вредного действия антропогенных факторов. Этих недостатков лишены биологические методы (биоиндикация и биотестирование) оценки качества вод [1]. Ручейники (Trichoptera) составляют отряд амфибиотических насекомых с полным превращением (Holometabola), у которых преимагинальные фазы развиваются в водных экосистемах, а имаго - в наземных. Личинки ручейников (Trichoptera) являются важнейшим компонентом донных биоценозов большинства пресноводных водоемов. Их естественное распределение и видовой состав в любом типе водоема зависит от многих факторов, как биотических, так и абиотических [2].

По особенностям экологии личинок большинство ручейников являются олигосапробами, а их высокая требовательность к развитию в чистой воде делает ручейников одними из важнейших биоиндикаторов качества воды и, как следствие, окружающей водоем среды [3-5]. Поскольку под воздействием антропогенных факторов в настоящее время усиливается загрязнение вод, то проблема повышения качества воды и быстрая диагностика ее загрязненности приобретают особо важное экологическое значение. В данном аспекте ручейники, выступающие в качестве одного из основных компонентов водных экосистем, имеют большое экологическое значение. Эта важная экологическая особенность ручейников остается пока слабо изученной для всех экосистем России [6].

Исходя из вышеизложенного, цель данной работы - анализ возможности использования личинок ручейников подотряда Integripalpia для повышения значимости биоиндикационных исследований в ходе экологического мониторинга рек Южного Урала.

Для достижения цели с 2005 по 2016 гг. решались две задачи:

1) сбор личинок ручейников подотряда Integripalріа в районах 17 государственных водопостов, находящихся на реках, протекающих по территории Южного Урала;

2) сопряженный анализ связи динамики постоянства видов личинок ручейников подотряда Integripalріа на вышеуказанных створах с гидрохимическими показателями, отражаемыми в ежегодно публикуемых государственных докладах «О состоянии природных ресурсов и окружающей среды республики Башкортостан» за 2006-2016 годы.

\section{материалы и методы}

Сбор личинок ручейников на каждом створе осуществлялся с применением ручного сбора и осмотра лежащих в воде предметов: камней, коряг и т.п. в соответствии с «Руководством по гидробиологическому мониторингу пресноводных экосистем» [7] с грунта на 10 участках (расстояние между участками $\approx 100-150$ м) ручным способом в районах 17 государственных водопостов: на р. Белой - район ж/д станции «Шушпа» (створ 1), р-н Д/О «Арский камень» (створ 2), выше г. Мелеуз (створ 3), ниже г. Мелеуз (створ 4), выше г. Салават (створ 5), ниже г. Ишимбай (створ 6), выше г. Стерлитамак (створ 7), ниже г. Стерлитамак (створ 8), ниже п. Прибельский (створ 9), выше г. Уфа (створ 10); на р. Большой Нугуш (с. Новосеитово) (створ 11), р. Ашкадар (в черте г. Стерлитамак) (створ 12), р. Селеук (д. Нижнеиткулово) (створ 13), р. Инзер (д. Азово) (створ 14), р. Юрюзань (д. Чулпан) (створ 15), р. Зилаир (с. Зилаир) (створ 16) и р. Большой Ик (село Мраково) (створ 17).

Для оценки постоянства видов (С) (в долях единицы) на биотопах использовалась формула: $\mathrm{C}=\mathrm{n} / \mathrm{N}$, где $\mathrm{n}$ - число выборок, содержащих изучаемый вид, $\mathrm{N}$ - общее число взятых выборок. Наименование категорий постоянства видов приводится по А.С. Степановских [8]. В зависимости от значения постоянства вида на створе определялись следующие категории: постоянные виды - $(C>0,5)$; добавочные виды - $(0,25<C<0,5)$; случайные виды - $(C<0,25)$.

Определение видовой принадлежности личинок ручейников проводилось непосредственно на створе по «Определителю пресноводных беспозвоночных России...» [9].

В качестве гидрохимических характеристик использовались такие показатели, как содержание в речных водах соединений марганца, никеля и железа, нефтепродуктов, фенолов, азота аммонийного, меди, цинка, ХПК, БПК , сульфатов, хлоридов, азота нитритного и удельный комбинаторный индекс загрязненности воды (УКИЗВ), отражаемых в ежегодно публикуемых государственных докладах «О состоянии природных ресурсов и окружающей среды республики Башкортостан» за 2006-2016 годы [10-16].

Статистическая обработка материала проводилась в прикладной программе Excel for Windows.

\section{Результаты исследований и их обсуждение}

Всего в ходе исследований в реках Южного Урала были выявлены личинки 7 видов ручейников, относящихся к подотряду Integripalpia (которые относительно легко определяются визуально, что очень важно для проведения регулярных биомониторинговых исследований на водотоках), принадлежащих к 4 семействам (табл. 1)

Анализ постоянства личинок ручейников, относящихся к подотряду Integripalpia, обитающих в реках Южного Урала показал, что все виды на створах могут быть постоянными, добавочными и случайными (табл. 2).

Анализ динамики постоянства личинок ручейников, относящихся к подотряду Integripalpia, на биотопах в реках Южного Урала за период с 2005 по 2016 годы показал, что на изученных створах относительным постоянством характеризуются H. Interpunctatus и A. soror, что свидетельствует об адаптации данных видов к экологическим условиям на разнокачественных изученных участках рек. Другие виды ручейников (особенно S. pallipes) обладают значительной динамикой постоянства по годам исследований.

Анализ динамики УКИЗВ в воде изученных рек Южного Урала за период с 2006 по 2015 годы показал, что данный показатель значительно колеблется на ряде створов, но есть створы, где он довольно стабилен. Так, можно отметить, что для р. Белой и ее притока - р. Инзер в качестве фоновых по данному показателю за период исследований выявились створы выше города Мелеуз и в районе д. Азово (рис. 1). 
Таблица 1 - Систематическая принадлежность личинок ручейников, найденных в реках Южного Урала, относящихся к подотряду Integripalpia

\begin{tabular}{|c|c|}
\hline \multicolumn{2}{|r|}{ Семейство Goeridae (Ручейники прибрежные) } \\
\hline \multicolumn{2}{|r|}{ Род Silo Curtis, 1830} \\
\hline $\begin{array}{l}\text { Silo pallipes Fabricius, } \\
1781\end{array}$ & $\begin{array}{l}\text { Личинки семейства отличаются несколько изогнутым телом (7-13 мм), утолщениями } \\
\text { по бокам переднегруди и наличием зубцов на среднегруди. Брюшко обычно с ветвя- } \\
\text { щимися жабрами. Домики трубчатые, слабо изогнутые, из песчинок с крупными ка- } \\
\text { мешками по бокам }\end{array}$ \\
\hline \multicolumn{2}{|r|}{ Семейство Lepidostomatidae (Ручейники чешуеротые) } \\
\hline \multicolumn{2}{|r|}{ Род Lepidostoma Rambur, 1842} \\
\hline $\begin{array}{l}\text { Lepidostoma hirtum } \\
\text { Fabricius, } 1775\end{array}$ & $\begin{array}{l}\text { Личинка длиной 9-11 мм. Домики четырехгранные из детрита, находятся преимуще- } \\
\text { ственно на камнях }\end{array}$ \\
\hline \multicolumn{2}{|r|}{ Семейство Phryganeidae (Фриганеиды) } \\
\hline \multicolumn{2}{|r|}{ Род Phryganea L., 1758} \\
\hline $\begin{array}{l}\text { Phryganea bipunctata } \\
\text { Retzius, } 1783\end{array}$ & \begin{tabular}{|l} 
Длина личинки 30-40 мм. Домики строят из спирально уложенных четырехгранных \\
растительных кусочков. Домик крупнее личинки, и она в нем свободно передвигается
\end{tabular} \\
\hline \multicolumn{2}{|r|}{ Семейство Limnaphilidae (Ручейники настоящие) } \\
\hline \multicolumn{2}{|r|}{ Род Chaetopteryx Stephens, 1829} \\
\hline $\begin{array}{l}\text { Chaetopteryx villosa } \\
\text { Fabricius, } 1798\end{array}$ & $\begin{array}{l}\text { Длина личинки 14-16 мм. Личинки имеют одиночные жабры. Домик из песчинок и } \\
\text { детрита, иногда могут быть встроены кусочки хвои или тонких палочек }\end{array}$ \\
\hline \multicolumn{2}{|r|}{ Род Halesus Stephens, 1836} \\
\hline $\begin{array}{l}\text { Halesus interpunctatus } \\
\text { Zetterstedt, } 1840\end{array}$ & Личинки крупные. Домик состоит из косорасположенных частиц детрита \\
\hline \multicolumn{2}{|r|}{ Род Anabolia Stephens, 1837} \\
\hline $\begin{array}{l}\text { Anabolia soror } \\
\text { McLachlan, } 1875\end{array}$ & $\begin{array}{l}\text { Личинки длиной 18-22 мм. Домик из песчинок с прикрепленными с боков длинными } \\
\text { палочками, значительно превышающими длину домика из песчинок }\end{array}$ \\
\hline \multicolumn{2}{|r|}{ Род Grammotaulius Kolenati, 1848} \\
\hline $\begin{array}{l}\text { Grammotaulius atoma- } \\
\text { ris Fabricius, } 1793\end{array}$ & и 28-30 мм. Домики большие (до 50 мм) из растительных частиц \\
\hline
\end{tabular}

Таблица 2 - Среднее постоянство видов (С) личинок видов ручейников, относящихся к подотряду Integripalpia на створах (1-17) рек Южного Урала за период с 2005 по 2016 гг.

\begin{tabular}{|c|c|c|c|c|c|c|c|c|c|c|c|c|c|c|c|c|c|c|}
\hline \multirow{2}{*}{ Вид } & \multicolumn{17}{|c|}{ Створ } & \multirow{2}{*}{$P$} \\
\hline & 1 & 2 & 3 & 4 & 5 & 6 & 7 & 8 & 9 & 10 & 11 & 12 & 13 & 14 & 15 & 16 & 17 & \\
\hline S. pallipes & 0,4 & $\mathrm{H} / \mathrm{O}$ & 0,2 & 0,4 & 0,4 & 0,4 & 0,4 & 0,3 & 0,5 & 0,4 & 0,4 & 0,6 & 0,6 & 0,3 & 0,6 & 0,7 & 0,6 & 0,7 \\
\hline L. hirtum & $\mathrm{H} / \mathrm{O}$ & $\mathrm{H} / \mathrm{O}$ & 0,3 & 0,2 & 0,4 & 0,1 & 0,3 & 0,3 & 0,5 & 0,4 & $\mathrm{H} / \mathrm{O}$ & 0,4 & $\mathrm{H} / \mathrm{O}$ & 0,4 & $\mathrm{H} / \mathrm{O}$ & $\mathrm{H} / \mathrm{O}$ & 0,3 & 0,5 \\
\hline P. bipunctata & $\mathrm{H} / \mathrm{O}$ & 0,4 & 0,4 & 0,4 & 0,4 & 0,4 & 0,4 & 0,4 & 0,5 & 0,4 & 0,4 & 0,4 & 0,6 & 0,5 & 0,6 & 0,6 & 0,5 & 0,6 \\
\hline C. villosa & 0,3 & $\mathrm{H} / \mathrm{O}$ & 0,2 & 0,3 & 0,5 & 0,2 & 0,5 & 0,3 & 0,4 & 0,5 & 0,3 & 0,5 & 0,5 & 0,4 & 0,4 & 0,3 & 0,2 & 0,5 \\
\hline H. interpunctatus & 0,4 & 0,2 & 0,3 & 0,2 & 0,3 & 0,5 & 0,4 & 0,5 & 0,4 & 0,4 & 0,4 & 0,4 & 0,5 & 0,0 & 0,5 & 0,3 & 0,4 & 0,3 \\
\hline A. soror & 0,3 & 0,5 & 0,2 & 0,2 & 0,3 & 0,5 & 0,4 & 0,5 & 0,3 & 0,5 & 0,3 & 0,5 & 0,5 & 0,5 & 0,4 & 0,5 & 0,2 & 0,3 \\
\hline G. atomaris & $\mathrm{H} / \mathrm{O}$ & 0,4 & 0,1 & 0,2 & 0,2 & 0,3 & 0,3 & 0,3 & 0,3 & 0,4 & 0,2 & 0,3 & 0,4 & 0,3 & 0,6 & 0,5 & $\mathrm{H} / \mathrm{O}$ & 0,6 \\
\hline
\end{tabular}

Примечание. Категории постоянства вида: $C<0,25$ - случайные виды, $0,25<C<0,5$ - добавочные виды, $C>0,5$ - постоянные виды; $н / o-$ не обнаруженные на створе виды за период исследования. $P=\max -\min$.

На рисунках 2 и 3 показана динамика постоянства личинок ручейников, относящихся к подотряду Integripalpia, отмеченных за период с 2005 по 2016 гг. на этих участках рек.

Анализ тесноты связи между постоянством личинок ручейников, относящихся к подотряду Integripalpia, и гидрохимическими показателями, а также регрессионные модели прогнозирования их постоянства от уровня содержания поллютантов в воде рек Южного Урала показаны в табл. 3.

Данный анализ показал, что отмечается, в основном, стимуляция увеличения постоянства личинок ручейников, относящихся к подотряду Integripalpia, поллютантами, содержащимися в воде на ряде изученных участках рек. В р. Белой проявляется стимулирующее влияние соединений марганца на увеличение встречаемости личинок S. pallipes (район ж/д станции «Шушпа») и H. interpunctatus (ниже г. Ишимбай), нефтепродуктов на увеличение встречаемости Самарский научный вестник. 2017. Т. 6, № 3 (20)
S. pallipes (ниже п. Прибельский), фенолов на увеличение встречаемости P. bipunctata (ДО «Арский камень» и ниже г. Ишимбай), железа на увеличение встречаемости A. soror (ниже г. Ишимбай) и C. villo$s a$ (выше г. Стерлитамака). Стимуляция повышения постоянства содержанием марганца отмечалась в p. Ашкадар (р-н г. Стерлитамака) у S. pallipes, нефтепродуктов в р. Селеук (д. Нижнеиткулово) у P. bipunctata и железа в р. Зилаир (с. Зилаир) у S. pallipes.

Снижение постоянства личинок ручейников при повышении содержания поллютанта в водах рек Южного Урала отмечено по влиянию нефтепродуктов на A. soror (ниже г. Стерлитамака) и P. bipunctata (ниже п. Прибельский).

Статистические материалы, представленные в табл. 3, позволяют спрогнозировать постоянство определенного вида личинок ручейников в зависимости от содержания химического поллютанта в его концентрации 1 ПДК. 


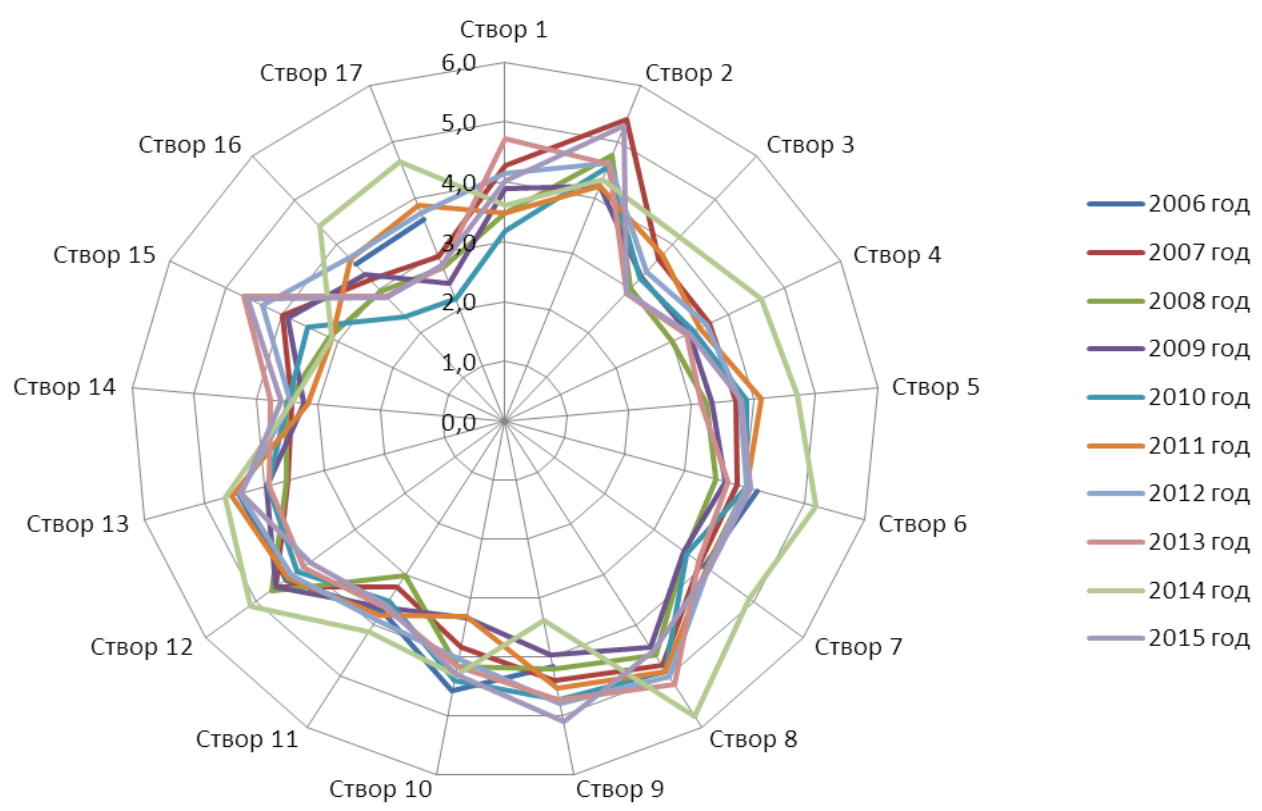

Рисунок 1 - Динамика УКИЗВ в воде рек Южного Урала за период с 2006 по 2015 годы
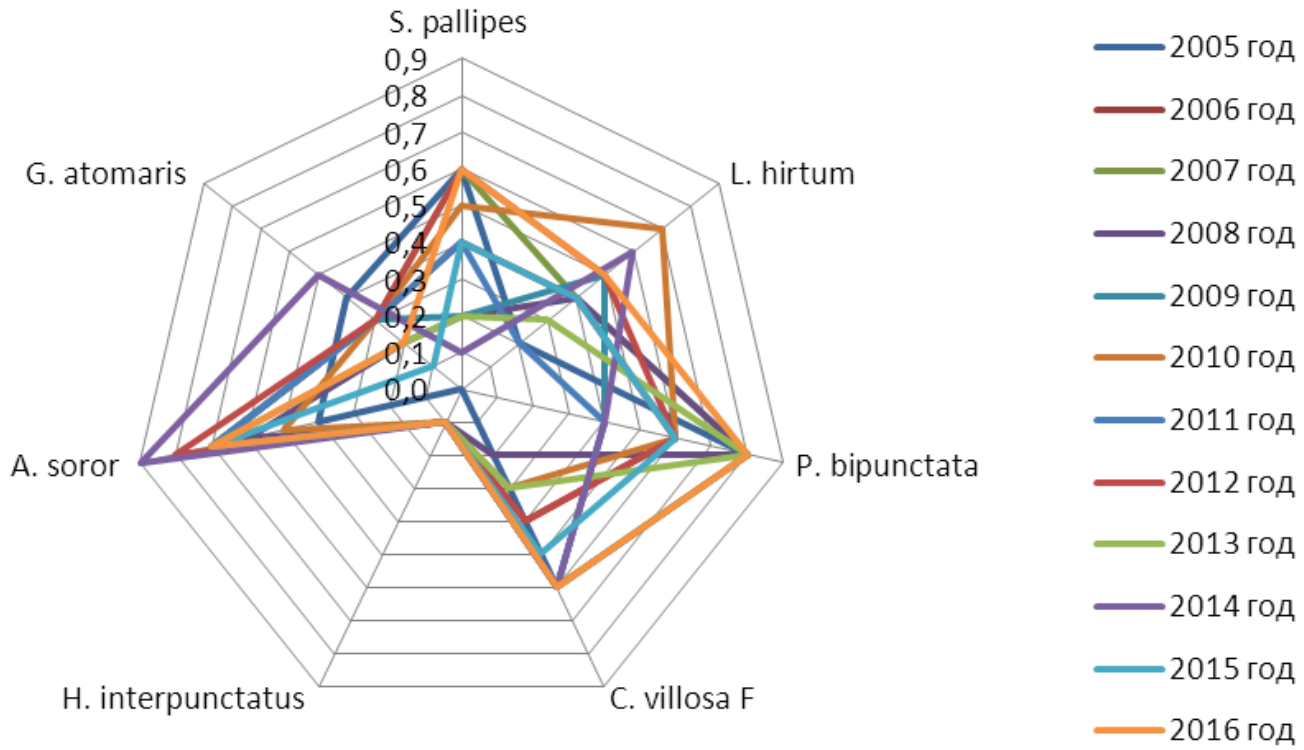

Рисунок 2 - Динамика постоянства личинок видов ручейников в р. Белая (выше г. Мелеуз)
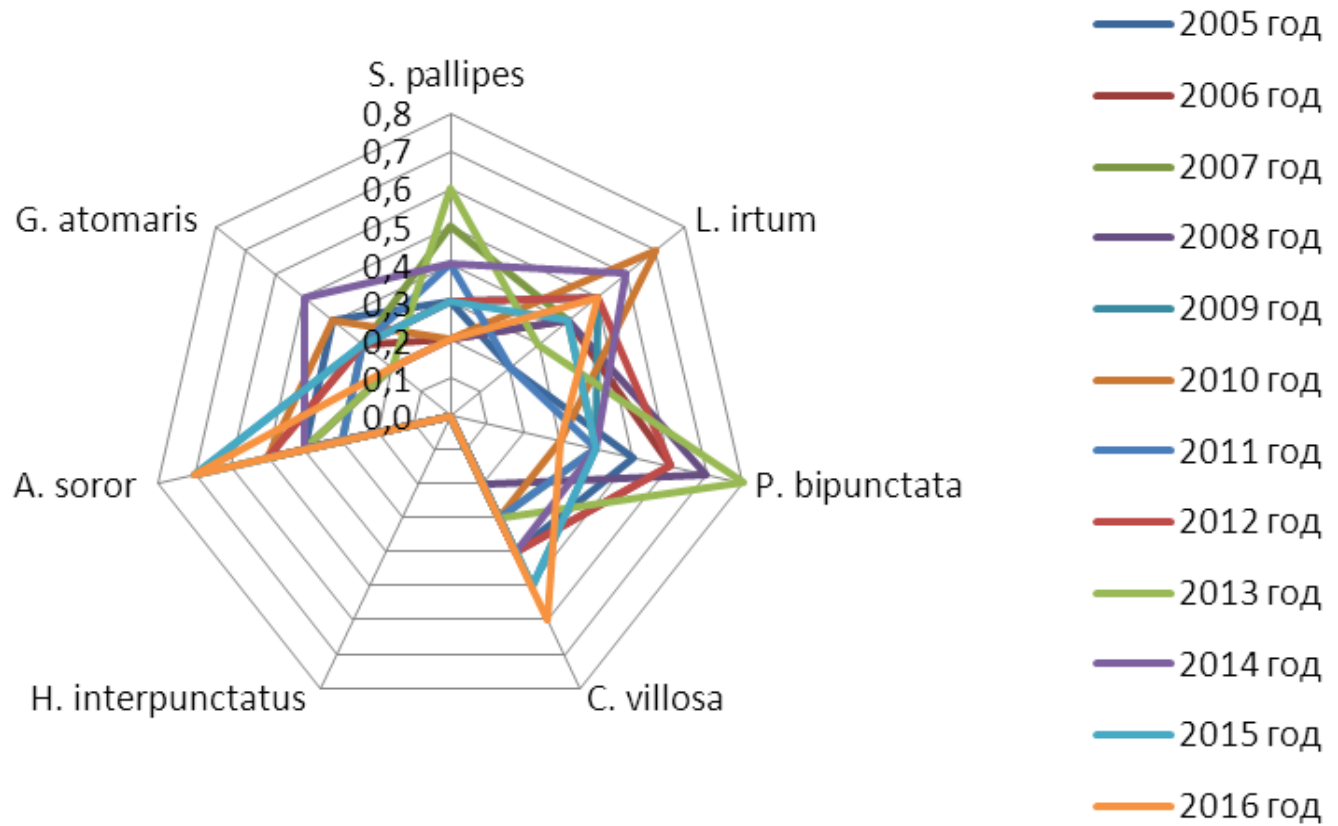

Рисунок 3 - Динамика постоянства личинок видов ручейников в р. Инзер (д. Азово) 
Таблица 3 - Корреляционно (r)-регрессионные (УР) зависимости между постоянством личинок ручейников ( $Y$ ) и гидрохимическими поллютантами $(x)$ в кратности превышения ПДК, содержащимися в водах рек Южного Урала

\begin{tabular}{|c|c|c|c|}
\hline$(Y)$ & $(x)$ & $r$ & УP \\
\hline \multicolumn{4}{|c|}{ Река Белая } \\
\hline \multicolumn{4}{|c|}{ Ж/д ст. «Шушпа» } \\
\hline S. pallipes & $\mathrm{Mn}$ & 0,7 & $Y=0 x+0,3$ \\
\hline \multicolumn{4}{|c|}{ ДО «Арский камень» } \\
\hline P. bipunctata & фен & 0,7 & $Y=0 x+0,7$ \\
\hline A. soror & $\mathrm{NO}_{2}$ & 0,7 & $Y=-0,3 x+0,8$ \\
\hline \multicolumn{4}{|c|}{ Ниже г. Ишимбай } \\
\hline H. interpunctatus & $\mathrm{Mn}$ & 0,7 & $Y=0,1 x+0$ \\
\hline A. soror & $\mathrm{Fe}$ & 0,7 & $Y=0,1 x+0$ \\
\hline P. bipunctata & фен & 0,8 & $Y=0,2 x+0$ \\
\hline \multicolumn{4}{|c|}{ Выше г. Стерлитамака } \\
\hline C. villosa & $\mathrm{Fe}$ & 0,7 & $Y=0 x+0,4$ \\
\hline \multicolumn{4}{|c|}{ Ниже г. Стерлитамака } \\
\hline A. soror & $\mathrm{H} / \Pi$ & $-0,7$ & $Y=-0,2 x+0,7$ \\
\hline \multicolumn{4}{|c|}{ Ниже п. Прибельский } \\
\hline S. pallipes & $\mathrm{H} / \Pi$ & 0,7 & $Y=0 x+0,4$ \\
\hline P. bipunctata & $\mathrm{H} / \Pi$ & $-0,7$ & $Y=-0,1 x+0,6$ \\
\hline \multicolumn{4}{|c|}{ Река Ашкадар (в черте г. Стерлитамака) } \\
\hline S. pallipes & $\mathrm{Mn}$ & 0,7 & $Y=-0,1+1,1$ \\
\hline \multicolumn{4}{|c|}{ Река Селеук (д. Нижнеиткулово) } \\
\hline S. pallipes & $\mathrm{Fe}$ & $-0,7$ & $Y=0 x+0,8$ \\
\hline P. bipunctata & $\mathrm{H} / \Pi$ & 0,8 & $Y=0,1 x+0,1$ \\
\hline \multicolumn{4}{|c|}{ Река Зилаир (с. Зилаир) } \\
\hline S. pallipes & $\mathrm{Fe}$ & 0,8 & $Y=0,1 x+0,2$ \\
\hline
\end{tabular}

Примечание. Мn - соединения марганца; $н / n-$ нефтепродукты; фен - фенолы; $\mathrm{Fe}$ - соединения железа; $\mathrm{NO}_{2}$ - азот нитритный; $\mathrm{NH}_{4}-$ азот аммонийный.

Таким образом, изучение динамики постоянства личинок ручейников, относящихся к подотряду Integripalpia, позволит использовать данный показатель в ходе биоиндикационных исследований качества воды рек Южного Урала, а при сочетании его с гидрохимическим анализом - выявить наиболее сильно действующие на водную экосистему загрязняющие химические вещества, входящие в состав сточных вод, сбрасываемых в поверхностные воды Южного Урала.

\section{Заключение}

Всего в ходе исследований с 2005 по 2016 гг. в реках Южного Урала была проанализирована динамика постоянства личинок 7 видов ручейников, относящихся к подотряду Integripalpia, принадлежащих к 4 семействам - семейство Goeridae (Silo pallipes Fabricius, 1781; семейство Lepidostomatidae (Lepidostoma hirtum Fabricius, 1775); семейство Phryganeidae (Phryganea bipunctata Retzius, 1783) и семейство Limnaphilidae (Chaetopteryx villosa Fabricius, 1798; Halesus interpunctatus Zetterstedt, 1840; Anabolia soror McLachlan, 1875; Grammotaulius atomaris Fabricius, 1793).

Анализ динамики УКИЗВ в воде рек Южного Урала за период с 2006 по 2015 годы показал, что он значительно колеблется на ряде створов, но есть участки, где отмечается его стабильность. Так, можно отметить, что для р. Белой и ее притока - p. Инзер в качестве фоновых с наиболее низким на период ис- следования данным показателем выявились створы выше города Мелеуз и в районе д. Азово.

На р. Белой выше г. Мелеуз и на р. Инзер в районе д. Азово наиболее динамично постоянство личинок ручейников A. soror и P. bipunctata соответственно, что, по-видимому, связано с динамикой гидрохимического режима на этих участках рек.

Относительную стабильность постоянства в р. Белой выше г. Мелеуза показали личинки ручейника S. pallipes, что, по-видимому, свидетельствует об адаптации данного вида к экологическим условиям на этом участке реки. В р. Инзер (р-н д. Азово) относительная стабильность постоянства не обнаружена ни у одного из изученных видов.

Построение корреляционно-регрессионных моделей показало значительную силу связи между постоянством ряда личинок ручейников и химическими поллютантами на разнотипных речных участках. В основном отмечается стимуляция увеличения постоянства личинок ручейников, относящихся к подотряду Integripalpia, содержанием поллютантов в воде на ряде изученных участках рек. В р. Белой проявляется стимулирующее влияние соединений марганца на увеличение встречаемости личинок S. pallipes (район ж/д станции «Шушпа») и H. interpunctatus (ниже г. Ишимбай), нефтепродуктов на увеличение встречаемости S. pallipes (ниже п. Прибельский), фенолов на увеличение встречаемости P. bipunctata (ДО «Арский камень» и ниже г. Ишимбай), железа на увеличение встречаемости A. soror (ниже г. Ишимбай) и C. villosa (выше г. Стерлитамака). Стимуляция повышения постоянства содержанием марганца отмечалась в р. Ашкадар (р-н г. Стерлитамака) у S. pallipes, нефтепродуктов в р. Селеук (д. Нижнеиткулово) у P. bipunctata и железа в р. Зилаир (с. Зилаир) у S. pallipes.

Снижение постоянства личинок ручейников при повышении содержания поллютанта в водах рек Южного Урала отмечено по влиянию нефтепродуктов на A. soror (ниже г. Стерлитамака) и P. bipunctata (ниже п. Прибельский).

Исследования динамики постоянства личинок ручейников, относящихся к подотряду Integripalpia, позволят использовать данный показатель в ходе биоиндикационных исследований качества рек Южного Урала, а при сочетании его с гидрохимическим анализом выявить наиболее сильно действующие на водную экосистему загрязняющие химические вещества, входящие в состав сточных вод, сбрасываемых в поверхностные воды Южного Урала.

\section{СПИСОК ЛИТЕРАТУРЫ:}

1. Абакумов В.А., Сущеня Л.М. Гидробиологический мониторинг пресноводных экосистем и пути его совершенствования // Экологические модификации и критерии экологического нормирования: труды международного симпозиума. М., 1991. С. 41-51.

2. Гигиняк И.Ю. Видовое разнообразие и биотопическая приуроченность личинок ручейников (Trichoptera) в озерных и речных экосистемах центральной и северной частей Беларуси // Проблемы водной энтомологии России и современных стран: мат-лы III Всероссийского симпозиума по амфибиотическим и водным насекомым. Воронеж: Издательско-полиграфический центр Воронежского государственного университета, 2007. С. 58-65. 
3. Лепнева С.Г. Личинки и куколки подотряда кольчатощупиковых (Annulipalpia). Фауна СССР. Т. 2. Вып. 1. М.-Л.: Наука, 1964. 563 с.

4. Росс Г., Росс Ч., Росс Д. Энтомология. Пер. с англ. М.: Мир, 1985. 576 с.

5. Иванов В.Д., Григоренко В.Н., Арефина А.Т. Отряд ручейники (Trichoptera) // Определитель пресноводных беспозвоночных России и сопредельных территорий. Т. 5. Высшие насекомые / под общ. ред. С.Я. Цалолихина. СПб.: Наука, 2001. С. 7-72.

6. Лавров И.А. Эколого-фаунистические особенности ручейников (Hexapoda: Trichoptera) бассейна реки Клязьмы: автореф. дис. ... канд. биол. наук. Владимир, 2011. 25 с.

7. Руководство по гидробиологическому мониторингу пресноводных экосистем / под ред. В.А. Абакумова. СПб.: Гидрометеоиздат, 1992. С. 131-150.

8. Степановских А.С. Экология: учебник для вузов. М.: Юнити-Дана, 2001. С. 288.

9. Определитель пресноводных беспозвоночных России и сопредельных территорий. Т. 5. Высшие насекомые / под общ. ред. С.Я. Цалолихина. СПб.: Наука, 2001. 824 с.
10. Государственный доклад «О состоянии природных ресурсов и окружающей среды республики Башкортостан в 2005 году». Уфа, 2006. 197 с.

11. Государственный доклад «О состоянии природных ресурсов и окружающей среды республики Башкортостан в 2006 году». Уфа, 2007. 200 с.

12. Государственный доклад «О состоянии природных ресурсов и окружающей среды республики Башкортостан в 2007 году». Уфа, 2008. 217 с.

13. Государственный доклад «О состоянии природных ресурсов и окружающей среды республики Башкортостан в 2008 году». Уфа, 2009. 200 с.

14. Государственный доклад «О состоянии природных ресурсов и окружающей среды республики Башкортостан в 2009 году». Уфа, 2010. 189 с.

15. Государственный доклад «О состоянии природных ресурсов и окружающей среды республики Башкортостан в 2010 году». Уфа, 2011. 343. 197 с.

16. Государственные доклады «О состоянии природных ресурсов и окружающей среды республики Башкортостан», 2011-2016 [Электронный ресурс] // http:// ecology.bashkortostan.ru/presscenter/lectures.

\section{REPRESENTATIVES OF CADDIS FLIES OF INTEGRIPALPIA SUBORDER IN THE SYSTEM OF ENVIRONMENTAL MONITORING OF THE SOUTH URAL RIVERS}

\section{(C) 2017}

Chaus Boris Yuryevich, candidate of biological sciences, associate professor of Biology Department Sterlitamak branch of Bashkir State University (Sterlitamak, Republic of Bashkortostan, Russian Federation)

Abstract. In the following paper the author tries to find a possibility to use larvae of caddis flies of Integripalpia suborder to increase a significance of bioindicator researches during environmental monitoring of the South Ural rivers. Analysis of caddis flies types constancy was carried out in 17 state water posts on the rivers flowing across the territory of South Ural from 2005 to 2016. As chemical characteristics such indexes as content in river waters of compounds of manganese, nickel and iron, oil products, phenols, ammonium nitrogen, coppers, zinc, COD, BOD 5 , sulfates, chlorides, nitrite nitrogen were used. Specific combinatorial index of water impurity was used as a complex index. In total constancy evolution of 7 species of larvae of caddis flies of Integripalpia suborder was analyzed. It's the first time the author has made a list of constant, additive and casual types of Integripalpia on the studied territory. The author has revealed significant correlative dependences between constancy of larvae of species of caddis flies with a number of hydro chemical indexes. The author has made regression models used to forecast constancy of larvae of Integripalpia suborder types depending on concentration of the pollutant containing in river waters.

Keywords: bioindication; caddis flies; larvae of caddis flies; Integripalpia suborder; South Ural; constancy of types; constancy evolution; hydro chemical indexes; pollutant; specific combinatorial index of water impurity; correlative models; regression models.

УДК 504.53:57.044

Статья поступила в редакцию 21.05.2017

\section{МЕТОДОЛОГИЧЕСКИЕ ПОДХОДЫ К ОЦЕНКЕ ЗАГРЯЗНЕНИЯ ТЯЖЁЛЫМИ МЕТАЛЛАМИ ПОЧВ УРБОЭКОСИСТЕМ}

(C) 2017

Юдина Елена Валериевна, начальник отдела регионального государственного экологического надзора и анализа состояния окружающей среды

Министерство природных ресурсов и экологии Республики Хакасия (2. Абакан, Российская Федерация)

Аннотация. В статье представлены данные оценки загрязнения тяжёлыми металлами почв города Абакана, основным источником поступления которых является автотранспорт. Оценка загрязнения верхних горизонтов почв, расположенных вблизи четырех основных автомагистралей города, проведена путем соотнесения с установленными нормативами, с данными содержания в почвах, испытывающих минимальную антропогенную нагрузку, данными по содержанию в почвообразующей породе территории города. Максимальные концентрации элементов зафиксированы на участке с очень высокой степенью транспортной нагрузки, что подтверждает значимость роли автотранспорта как основного источника поступления поллютантов. При расчете суммарного показателя загрязнения $\left(\mathrm{Z}_{\mathrm{c}}\right)$ для подвижных форм с использованием данных для почв с минимальной антропогенной нагрузкой, на всех автомагистралях, категория определена как «опасная». Аналогичный показатель, рассчитанный на основе данных содержания в почвообразующей породе, позволил 